\title{
The Burden of Natural and Technological Disaster-related Mortality on Gross Domestic Product (GDP) in the WHO Africa Region
}

\author{
Joses M. Kirigia ${ }^{1 *}$, Luis G. Sambo ${ }^{1}$, W. Aldis $^{1}$ and Germano M. Mwabu ${ }^{2}$
}

1. World Health Organization Regional Office for Africa, Parirenyatwa Hospital, P.O. Box BE773, Harare, Zimbabwe. Tel: +263-91-238563. Email: \{kirigia@whoafr.org\}. 2. Department of Economics, University of Nairobi, Kenya

* To whom correspondence should be addressed.

\section{SUMMARY}

The WHO Africa region has the highest disaster mortality rate compared to the other five regions of the organization. Those deaths are hypothesized to have significantly negative effect on per capita gross domestic product (GDP). The objective of this study was to estimate the loss in GDP attributable to natural and technological disaster-related mortality in the WHO African Region. We estimated the impact of disaster-related mortality on GDP using double-log econometric model and cross-sectional data (from the UNDP and the World Bank publications) on 45 out of 46 countries in the WHO African Region. The coefficients for capital (K), educational enrolment (EN), life expectancy (LE) and exports (X) had a positive sign; while imports (M) and disaster mortality (DS) were found to impact negatively on GDP. The above mentioned explanatory variables were found to have statistically significant effect on GDP at $5 \%$ level in a tdistribution test. Disaster mortality of a single person was found to reduce GDP by US\$0.018. We have demonstrated that disaster mortality has a significant negative effect on GDP. Thus, as policy-makers strive to increase GDP through capital investment, export promotion and increase in educational enrolment, they should always recall that investments in strengthening national capacity to mitigate the effects of national disasters expeditiously and effectively shall yield significant economic returns.

[Afr. J. Health Sci. 2002; 9: 169-180]

\section{Introduction}

This paper focuses on the economic impact of deaths attributable to natural and technological disasters. Natural disasters include cyclones, hurricanes, typhoons, drought, earthquakes, epidemics and famine (excluding famine related to conflict) [1]. Technological disasters include accidents, chemical accidents and urban fires.

The UNDP estimated that from 1980 to 1999, globally, an annual average of $1,429,412$ people were killed by disasters [1]. About $96.4 \%(1,377,318)$ of those deaths occurred in developing countries; and $39.2 \%(539,597)$ of them occurred in the
African Region. Natural hazards resulted in $57 \%$ of all disasters in Africa and $28 \%$ of emergency-related mortality [2].

Although natural disasters cannot be prevented, better preparedness for and effective response to such disasters when they occur could help reduce the number of human deaths, extent of damage to property, including capital investments. On the other hand, it is possible to implement measures for preventing technological disasters, and mitigating their adverse effects on human lives, infrastructure and property, if and when they occur. Due to increased vulnerability of people and property to 
natural disasters, the United Nations General Assembly adopted a resolution in December 1987 designating the $1990 \mathrm{~s}$ as the International Decade for Natural Disaster Reduction (IDNDR). The resolution stated:

"The objective of the IDNDR is to reduce through concerted international action, especially in developing countries, the loss of life, property damage and social and economic disruption caused by natural disasters such as earthquakes, windstorms, tsunamis, floods, landslides, volcanic eruptions, wildfires, grasshopper and locus infestations, drought and desertification and other calamities of natural origin" [3].

It called upon all governments to: formulate national disaster-mitigation programmes; participate in concerted international action to reduce the effects of natural disasters; establish appropriate national committees in co-operation with the relevant scientific and technological institutions and organizations; mobilize the necessary support from the public and private sectors; take appropriate measures to increase public awareness of the potential risk and the importance of preparedness, prevention, and relief; pay special attention to activities aimed at reducing vulnerability of hospitals and health centers, food storage facilities, human shelter and other social and economic infrastructures; improve availability of appropriate emergency supplies through storage of such supplies in disaster-prone areas.

Cognizant of the high frequency of disasters (with the accompanying adverse effects on health and its risk factors) in the Region, and in an effort to implement the UN resolution on IDNDR, the WHO Regional Committee for Africa adopted a series of resolutions [4-7] urging Member States to allocate adequate resources for strengthening their technical, institutional/organizational and logistical capacity in emergency preparedness and response. These resolutions culminated in the adoption of the regional strategy for emergency and humanitarian action by the Regional Committee in 1997. The strategy calls for inter-disciplinary and multi-sectoral approach to emergency management, i.e. prevention, preparedness, readiness and response [2].

This study attempts to estimate the loss in GDP attributable to mortality caused by natural and technological disasters in the WHO African Region. This information could be used in various ways:

i. To inform choices in resource allocation by eliminating resource consequences of disasters in comparison with those of other health problems.

ii. To sensitize non-health sectors (especially Ministries of State, Finance and Economic Development/Planning) in order to generate political and economic support for the emergency preparedness and response.

iii. To garner international support for emergency preparedness and response in the Region.

iv. To simulate the benefits of policy interventions/measures geared at attenuating the negative effects of disasters on GDP.

\section{Materials and Methods}

\section{Conceptual Framework}

The study used Production Function (PF) analytical framework to estimate the loss in GDP attributable to death related to disasters in the Region. A PF describes the transformation of factors of production (inputs) into outputs with its existing technology. The general mathematical form of production function is $\mathrm{Y}=\mathrm{f}(\mathrm{L}, \mathrm{K}, \mathrm{R}, \mathrm{S}, v$, $\gamma$ ), where $\mathrm{Y}=$ Output, $\mathrm{L}=\mathrm{Labour}$ (skilled, semi-skilled and unskilled), $\mathrm{K}=$ Capital (buildings, equipment and inventories), $\mathrm{R}=$ raw materials, $S=$ Land input (which encompasses all natural resources), $v=$ returns to scale and $\dot{\gamma}=$ efficiency parameter, measuring the entrepreneurialorganizational aspects of production [8]. 
Thus, a PF shows the maximum amounts of the various combinations of outputs that a country can produce with its existing resources and techniques [9].

The gross domestic product (GDP) is one of the main national output measures. GDP is the sum of total value of consumption expenditure; total value of investment expenditure; government purchases of goods and services; and net exports (i.e. exports minus imports) of goods and services. It can also be viewed as the total value of consumption expenditure; gross private saving (including business and personal saving); net tax revenues (tax revenue minus domestic transfer payments, net interest paid, and net subsidies); and total private transfer payments to foreigners [10].

Intuitively, disaster-related deaths can impact on the production of GDP in a number of ways. First they reduce the quantity of labour force, and hence, the number of people involved in output production. Disasters are non-selective and universal, they maim and kill the unskilled, semi-skilled, highly skilled labour force and entrepreneurs, who are acutely in short supply in the African Region. The attrition of the latter three categories of human resources, will obviously impact negatively on GDP.

Second, the typically high funeralrelated costs might force affected households to liquidate/sell off some of the output producing assets (e.g. land, farm machinery and equipment) to pay for funerals. In third world economies, characterized by high levels of labour force underemployment/unemployment and low levels of capital investment, depletion of the latter spontaneously leads to a reduction in output.

Third, given the high levels of poverty across the African Region, the bereaved children may be forced to drop out of school due to lack of school fees, or to work in order to compensate for the lost household income. And that of course would have adverse repercussions on human capital creation (on the quality and quantity of future labour force), and hence, on sustainability of GDP and its growth.

Fourth, premature death of people in active labour force may lead to a reduction in total household consumption expenditure, government tax revenues, private business and personal savings, and hence, the resources available for investment purposes.

Fifth, when disasters strike, households, governments and non-governmental organizations are forced to divert resources from productive sectors into reconstruction/rehabilitation programmes. And often, such programmes do not make net contributions to the GDP.

Formally, the effect of disaster-related mortality on the per capita gross domestic product can be expressed as follows:

$G D P=f(D, L, K, \grave{H K}, E A ; O E, D S) . .(i)$

where: GDP = real per capita gross domestic product, i.e. real value of annual volume of goods and services divided by population; $\mathrm{D}=$ Land, $\mathrm{L}=$ Labour input $(\geq$ 15 years); $\mathrm{K}=$ Capital stock; HK = Human capital, i.e. the skills and knowledge embodied in a person; EA = Entrepreneurial ability (the ability to plan, organize and produce new commodities); $\mathrm{OE}=$ Openness of the economy; DS = Number of people killed by disasters.

Equation (i) shows the effect of 'DS' on GDP, holding the effects of D, L, K, HK, and EA constant. If deaths caused by disasters are a burden on the economies of African countries, the coefficient for 'DS' variable would be expected to assume a negative sign. The effects of the explanatory variables on the dependent variables (GDP are unlikely to be linear, thus, in this study we shall estimate Cobb-Douglas production function of the following form: 
where: LE is life expectancy; $\mathrm{EN}$ is school enrolment; $\mathrm{X}$ is exports and $\mathrm{M}$ is imports.

Taking logarithms of both sides of equations (ii), we obtain the following log-log (or double$\log , \log$-linear or constant elasticity model):

$$
\begin{aligned}
\log G D P & =\log a+\beta_{1} \log D+\beta_{2} \log L+\beta_{3} \log K+\beta_{4} \log L E \\
& +\beta_{5} \log E N+\beta_{6} \log X+\beta_{7} \log M+\beta_{8} \log D S+E \ldots
\end{aligned}
$$

where: $\log$ is the natural $\log$ (i.e., $\log$ to the base $\mathrm{e}$, where e equals 2.718 ; ; $\mathrm{a}$ is the intercept term (i.e. the output if all the explanatory variables included in the model were equal to zero); $\beta$ s are the coefficients of elasticity, which can take any value between 0 (perfectly inelastic) to $\mathbf{0 0}$ (perfectly/infinitely elastic); and $\varepsilon$ is a random (stochastic) error term capturing all factors that affect gross domestic product but are not taken into account explicitly in the model [11]. Why, readers might ask, did the authors choose to include the above mentioned variables in the model?

Land includes all natural resources like soil, mineral deposits, rivers, sea, fish, forests, etc. Civilizations have drawn great strength from productive land resources [12]. It is common knowledge that agriculture is the backbone of majority of the economies in the African region. Most of the African people earn their livelihood either directly (through farming) or indirectly (in agro-processing industries) from land. More than three decades ago, Professor Gunnar Myrdal [13] a Nobel Laureate in Economics, made the following remarkable statement: "it is in the agricultural sector that the battle for longterm economic development will be won or lost". That statement is very pertinent to the African region even today. We would expect a positive relationship between arable land per capita and GDP per capital, since agriculture makes a substantive contribution to the latter.

Capital means the stock of physical reproducible factors of production, i.e. tangible investment goods, e.g., plant and equipment, machinery, buildings, etc [14] Development economists have argued that capital formation (i.e. investment in capital goods that leads to increase in capital stock, national output and income) is the key to economic growth and development. The process of capital formation entails:

i. An increase in the volume of real savings;

ii. The existence of credit and financial institutions to mobilize savings and channel them to productive use; and

iii. The use of these savings for investment in capital goods [9].

There are a number of ways of bringing about capital accumulation/formation;

i. Forced savings through taxation (to siphon them off into the coffers of the state, deficit financing and borrowing the public

ii. Government could use the profits earned by public corporations for capital formation

iii. Government could restrict importation of luxury consumer commodities and instead provide incentives for importation of goods

iv. Removal of disguised unemployed agricultural workers whose marginal productivity is negligible or zero from the land and employing them on various capital projects such as irrigation, roads, railways, hospitals, house buildings, etc.

v. Start joint ventures whereby foreign investors bring technical know-how along with capital, and train local labor and entrepreneurship 
vi. Negotiate for favourable terms of trade, save part of the export earnings, and invest them in acquisition of capital stocks. Since capital is acquired primarily to boost production, one would expect a direct (positive) relationship between capital investments and GDP per capita.

Labour force refers to all economically active persons, including the armed forces and the unemployed, but excluding housewives, students, and economically inactive groups [14]. Given the high levels of unemployment and underemployment among African economies, it is difficuit a priori to predict whether an increase in the labour force, with stock of capital held constant, would translate into an increase in total output (GDP).

Human capital is the productive investments embodied in human beings. These include skills, abilities, ideals, values and health resulting from expenditures on education, on-the-job training programmes, and health care (including curative, rehabilitative, preventive and promotive care). It is the human resources (i.e. the quantity and quality of a nation's labour force) of a nation, not its physical capital or its natural resources, that ultimately determines the character and pace of its economic and social development [14]. Unlike capital and natural resources, which are passive factors of production, human beings are the active agents who accumulate capital, exploit natural resources, build social, cultural, economic and political institutions, and carry forward national development [15]. To be consistent with the past production function studies on economic burden of health problems [16], in this study we have used two proxies of human capital:

i. Combined primary, secondary and tertiary school enrolment ratio (EN) as a proxy for education-related human capital. The rationale being that there is evidence in economics of education literature that schooling raises earnings and productivity mainly by providing knowledge, skills, and a way of analyzing problems [17]. Some studies have shown that education promotes health, reduces likelihood of smoking [18], increases the likelihood of toilet ownership [19], improves probability of use of contraceptives [20], improves child survival, raises the propensity to vote (i.e. participate in democratic process), and stimulates the appreciation of classical music, literature, and even sports [21]; those being non-monetary benefits. Other studies have also found that health education knowledge regarding modes of transmission of HIV/AIDS, its prevalence and preventive measures empowered women to exercise their rights to unforced choice to have safe sexual relationships [22]. Given the direct relationship between education and earnings, it is expected that the education variable (EN) will have a positive impact on the GDP.

ii. We have used life expectancy at birth (LE) to capture health-related human capital. Of course, we are aware that health consists of both health-related quality of life and quantity of life. Since in this study we are concerned with only the mortality aspect of disasters, it made sense to include only life expectancy. According to the World Bank [23] evidence showing that poor health (from high morbidity and mortality) imposes immense economic costs on individuals, households, and society at large is strong worldwide. Becker [17] argued that a decline in the death rate at working ages may improve earning prospects by extending the period during which earnings are received. Ram [24] found a positive relationship between life expectancy and real GDP per capita. Keeping in view the foregoing arguments, one would expect life expectancy to have a positive partial effect on per capita GDP. 
All economies in the African region are open economies, which means that they do not exist in isolation but trade goods and services [25]. However, the degree of 'openness' varies considerably. In this study we have used exports and imports as a proportion of GDP as a measure of the degree of openness. Export $(\mathrm{X})$ is the value of all goods and non-factor services sold to the rest of the world; they include merchandise, freight, insurance, travel, and other non-factor services [14]. Since exports represent an injection of expenditure by foreigners into the domestic expenditure/income flow, it's expected to be directly related to GDP per capita.

Import $(\mathrm{M})$ is the value of all goods and non-factor services purchased from the rest of the world; they include consumer goods (e.g. pharmaceuticals, non-pharmaceutical supplies) and capital goods (e.g. machinery, equipment, medical technologies, vehicles). Thus, ' $M$ ' captures all expenditure on imports by all economic agents households, business enterprises, the government sector, parastatal institutions, non-governmental organizations, etc. Imports (M) imply a leakage from the national income/expenditure flow to the rest of the world [26], implying that it would be expected to be inversely related to GDP.

The purpose of the current study was to estimate the loss in GDP attributable to natural and technological disaster-related deaths (DS). Thus, it is obvious that the variable had to be included in the analysis. If DS imposes an economic burden on the African economies, its coefficient would be expected to assume a negative sign.

\section{Data Sources and Analysis}

The data used to estimate equation (iii) were obtained from two sources. GDP per capita
(GDP), capital (K), school enrolment (EN), life expectancy (LE), exports (X), imports (M), and disaster deaths (DS) from UNDP [1]; arable land per capita (D); and labor force (L) from the World Bank [27].

The data analysis was done using the following steps:

a. The data were entered into the computer EXCEL spreadsheet program. The first column was occupied by the names and countries; the second column by per capita GDP; and the subsequent columns by each of the explanatory variables.

b. With exception of country names, data in the other columns were copied using the computer mouse.

c. Without exiting EXCEL, we opened STATA programme.

d. We then pasted the EXCEL file, copied in step ' $b$ ', on the STATA [27] editor/spreadsheet.

e. Since the variables in equation 'iii' are in logarithmic form, there was need to transform the dependent and independent variables into their logarithms. This was accomplished by typing the following command (as many times as the number of variables in the equation) into the commands. window for STATA: generate $\log G D P=$ in $(G D P)$. That is the command used to create the logarithm of GDP. Those for the dependent variables were generated in a similar manner.

f. The double-log model 'iii was estimated by typing the following command into STATA window: regress [ $\log G D P$, $\log \mathrm{D}, \log \mathrm{L}, \log \mathrm{K}, \log \mathrm{K}, \log \mathrm{LE}, \log \mathrm{EN}$, $\log \mathrm{X}, \log \mathrm{M}, \log \mathrm{DS}]$. The dependent and independent (explanatory) variables are defined in Table 1. 
TABLE 1: Variable Descriptions

\begin{tabular}{|c|c|}
\hline Variable & Variable Description \\
\hline GDP & $\begin{array}{l}\text { Per capita gross domestic product (GDP), i.e. real value of annual volume of } \\
\text { goods and services divided by population (in purchasing power parity US } \$ \text { ) }\end{array}$ \\
\hline $\mathrm{D}$ & Hectares of arable land per capita, i.e. total arable land divided by population \\
\hline $\mathrm{L}$ & $\begin{array}{l}\text { The number of people who are currently employed and people who are } \\
\text { unemployed but seeking work, as well as first-time job-seekers. }\end{array}$ \\
\hline $\mathrm{K}$ & $\begin{array}{l}\text { Capital stock proxied by gross domestic investment (as a percentage of GDP). It } \\
\text { consists of additions to fixed assets of the economy plus net changes in inventory }\end{array}$ \\
\hline $\mathrm{LE}$ & Life expectancy in years \\
\hline $\mathrm{EN}$ & Combined primary, secondary and tertiary gross enrolment ratio \\
\hline $\mathrm{X}$ & $\begin{array}{l}\text { Openness of economy proxied by exports of goods and services (each expressed } \\
\text { as a percentage of GDP) }\end{array}$ \\
\hline$\overline{\mathrm{M}}$ & $\begin{array}{l}\text { Openness of economy proxied by imports of goods and services (as a percentage } \\
\text { of GDP) }\end{array}$ \\
\hline DS & Number of people killed by natural and technological disasters in a year \\
\hline
\end{tabular}

\section{Results}

Table 2 presents the means and standard deviations of the untransformed values of the dependent and independent variables

\section{TABLE 2: Means and Standard Deviations}

\begin{tabular}{|l|r|r|}
\hline \multicolumn{1}{|c|}{ Variable } & \multicolumn{1}{c|}{ Mean } & \multicolumn{1}{c|}{$\begin{array}{l}\text { Standard } \\
\text { Deviation }\end{array}$} \\
\hline GDP & 2149.463 & 2388.444 \\
\hline Land (D) & 0.243 & 0.154 \\
\hline Labor (L) & $5,933,333$ & 8776000 \\
\hline Capital (K) & 22.053 & 13.431 \\
\hline Life expectancy (LE) & 51.117 & 8.414 \\
\hline Education (EN) & 46.732 & 19.55 \\
\hline Exports (X) & 32.713 & 21.792 \\
\hline Imports (M) & 45.993 & 30.334 \\
\hline Disaster-related deaths (DS) & 11991.044 & 48826.814 \\
\hline
\end{tabular}


Table 3 summarizes the GDP elasticities and slope coefficients. The adjusted Rsquared is 0.6888 , meaning that the fitted model explains about 69 per cent of variations of the dependent variable, i.e. GDP. The capital (K), life expectancy (LE), educational enrolment (EN) and exports (X) variables have a satisfactory significant (at $5 \%$ level) positive impact on GDP. On the other hand, the coefficients for imports (M) and disaster mortality (DS) have a statistically significant negative effect on the GDP per capita. The coefficient $\beta$ measures the elasticity of GDP with respect to a particular explanatory variable, that is the percentage change in GDP for a given small percentage change in explanatory variable in question. For example, the life expectancy (LE) elasticity of GDP is 1.396, implying that on the average a unit percentage increase in the life expectancy will cause a 1.396 percentage increase in the per capita GDP. Since the capital elasticity value of 1.396 is greater than 1 in absolute terms, we can say that GDP per capita is elastic, i.e. responsive to changes in capital investment.

Since elasticity is given by $\left[\partial \mathrm{GDP} / \partial \mathrm{R}_{\mathrm{i}}\right.$ ) $\left.x \quad\left(R_{i} / G D P\right)\right]$, we obtained the slopes coefficients in column 3 of Table 3 by applying the following formula: $\left[\left(G D P / R_{i}\right) x\right.$ $(\beta)]$. For instance, the slope for DS was obtained as follows: $[2,149.463 / 11991.044)$ $x(-0.102)]=-0.01828$. The interpretation of the slope coefficient -0.01828 is that if disaster-related deaths increases by one person, GDP per capita on the average decreases by US $\$-0.01828$, i.e. the

$$
\begin{aligned}
& \sum_{i=1}^{45}\left(D S_{A} \times G D P_{l}\right)=539,597 \times \$ 0.018=\text { US } \$ 9,712.7 \text {, here meanings of all the } \\
& \text { variables are as defined earlier. } \\
& \text { The life-time economic loss }(L T E L) \text { were estimated as follows: } \\
& \sum_{i=1}^{15}\left(A G E R-A G E_{D}\right) \times\left(D S_{A} \times G O P_{1}\right) \\
& =(55-30) \times(539597) \times(\text { US } \$ 0.018)=\text { CS\$242819, }
\end{aligned}
$$

Where: $A G E_{R}$ is the average retirement age in the Region, which was assumed to be 55 years; $\mathrm{AGE}_{\mathrm{R}}$ is the average age at disasterrelated death, which was assumed to be 30 years: and the other variables were defined earlier. The undiscounted lifetime GDP loss for the African region, estimated at US dollar per day. economic burden of a single disaster-related death.

\section{Discussion}

Disaster-related deaths were found to have a statistically significant negative effect on the GDP per capita. The disaster mortality elasticity of GDP was -0.102 . implying that on the average a unit percentage increase in the DS resulted in a 0.102 percentage decrease in the GDP per capita. Since the disaster mortality elasticity value of 0.102 is less than 1 in absolute terms, we can say that the GDP per capita is disaster mortality inelastic. A unit increase in disaster mortality was found to decrease GDP per capita by US\$0.01828, i.e. the economic burden of disaster mortality. In other words, an increase in mortality rate by 100 deaths reduces GDP per capita by only US\$1.828, i.e. 0.01828 times 100 people. The Appendix provides estimate of the annual (in column 3) and lifetime (in column 4) loss in GDP sustained by each country due to disaster deaths in 1999. The annual GDP loss (AGL) per country was obtained using the following formula: $\mathrm{DS}_{\mathrm{A}}$ $x \mathrm{GDP}_{\mathrm{L}}$, where $\mathrm{DS}_{\mathrm{A}}$ is the annual number of disaster-related deaths, and $\mathrm{GDP}_{\mathrm{L}}$ is the annual GDP loss per disaster-related death. For example, the loss sustained by Mozambique was estimated as follows: $113,974 \times$ US $\$ 0.018=$ US $\$ 2,052$. The annual GDP loss sustained by the 45 countries (contents of column 2) were obtained applying the following formula:

US $\$ 242819$ per 539597 disaster-related deaths an underestimate of their socioeconomic effects. Nevertheless it is a substantive loss in a region where about $50 \%$ of the population live on less than one 
TABLE 3: Effects of Various Explanatory Variables on GDP Per Capita

\begin{tabular}{|c|c|c|c|}
\hline Variable & $\begin{array}{l}\text { Elasticity } \\
\text { (t statistic) }\end{array}$ & $\begin{array}{c}\begin{array}{c}\text { Slope Coefficient } \\
\text { (t statistic) }\end{array} \\
\end{array}$ & $p>\left.\right|^{t} \mid$ \\
\hline $\log (D)$ & $\begin{array}{l}0.043 \\
(1.19)\end{array}$ & $\begin{array}{l}380.358 \\
(1.19) \\
\end{array}$ & 0.243 \\
\hline $\log (\mathrm{L})$ & $\begin{array}{l}-0.010 \\
(-1.22)\end{array}$ & $\begin{array}{l}-0.0000036 \\
(-1.22)\end{array}$ & 0.232 \\
\hline $\log (\mathrm{K})$ & $\begin{array}{l}0.545 \\
(2.33)^{*}\end{array}$ & $\begin{array}{l}53.120 \\
(2.33)^{*}\end{array}$ & 0.025 \\
\hline $\log (\mathrm{LE})$ & $\begin{array}{l}1.396 \\
(2.45)^{*}\end{array}$ & $\begin{array}{l}58.702 \\
(2.45)^{*}\end{array}$ & 0.019 \\
\hline$\overline{\log (\mathrm{EN})}$ & $\begin{array}{l}0.647 \\
(3.01)^{*}\end{array}$ & $\begin{array}{l}29.759 \\
(3.01)^{*}\end{array}$ & 0.005 \\
\hline $\log (X)$ & $\begin{array}{l}0.698 \\
(3.68)^{*}\end{array}$ & $\begin{array}{l}45.863 \\
(3.68)^{*} \\
\end{array}$ & 0.001 \\
\hline $\log (\mathrm{M})$ & $\begin{array}{l}-1.065 \\
(-3.67)^{*}\end{array}$ & $\begin{array}{l}-49.772 \\
(-3.67)^{*}\end{array}$ & 0.001 \\
\hline $\log (\mathrm{DS})$ & $\begin{array}{l}-0.102 \\
(-2.08)^{*}\end{array}$ & $\begin{array}{l}-0.018 \\
(-2.08)^{*}\end{array}$ & 0.044 \\
\hline Constant & $\begin{array}{l}0.261 \\
(0.12)\end{array}$ & & 0.907 \\
\hline
\end{tabular}

Number of observations $=45 ; \mathrm{F}(8,36)=13.18 ;$ Prob $>\mathrm{F}=0.0000$

Adjusted R-Squared $=0.6888$

${ }^{1}$ Average (across the 45 countries) GDP per capita and those for individual explanatory variables are used in estimating the slope coefficients. * means that the variable has a statistically significant impact on GDP per capita at $95 \%$ level of significance.

\section{Conclusion}

The key findings of this study are that:

(a). Disaster-related deaths have statistically significant negative effect on GDP;

(b) The annual GDP lost by the region has been estimated at US\$9,713; and

(c) The undiscounted lifetime GDP lost through death of 539,597 people was estimated at US\$242,819. We have demonstrated that disaster mortality has a significant negative effect on GDP. Thus, as policy-makers strive to increase GDP through capital investment, export promotion and increase in educational enrolment, they should always recall that investments in strengthening national capacity to mitigate the effects of national disasters expeditiously and effectively shall yield significant economic returns.

The production function approached employed in this study does not capture the full socioeconomic loss incurred by society as a result of disaster mortality. Therefore, there is need for further research to estimate economic burden of disaster mortality in a sample of countries in the Region, using micro-level costing and contingent willingness-to-pay [29] methods. The latter approach might enable the policy-makers to capture all socioeconomic losses related to disaster deaths. In addition, there is need for economic evaluations of the various aspects of disaster management so as to guide decision-making. 


\section{Acknowledgements}

This paper is dedicated to all victims of natural and technological disasters, whose lives are terminated before releasing their potential fully. We owe profound gratitude to Adonai Elohim for this opportunity to bequeath these thoughts to future generations.

\section{References}

1. UNDP. Human Development Report 2000: human rights and human development. New York: Oxford University press; 2000.

2. World Health Organization, Regional Office for Africa (WHO/AFRO). Regional Strategy for emergency and humanitarian action. Harare: WHO/AFRO; 1997.

3. United Nations General Assembly resolution AVRES/44/236. 1989.New York: United Nations.

4. WHO/AFRO. Regional Committee for Africa resolution AFR/RC40/R11. Harare: WHO/AFRO; 1990.

5. WHO/AFRO. Regional Committee for Africa resolution AFR/RC42/R11. Harare: WHO/AFRO; 1992.

6. WHO/AFRO. Regional Committee for Africa resolution AFR/RC44/R16. Harare: WHO/AFRO; 1994.

7. WHO/AFRO. Regional Committee for Africa resolution AFR/RC46/R4. Harare: WHO/AFRO; 1996.

8. Koutsoyiannis, A. Modern microeconomics. London: Macmillan; 1979.

9. Jhingan, M.L. The economics of development and planning. Delhi: Vikas Publishing House; 1982. pp.

10. Branson, W.H. Macroeconomic theory and policy. New York: Harper \& Row; 1979.

11. Gujarati, D.N. Basic econometrics. New York: McGraw-Hill Book Company; 1988.
12. Rao, P.K. Sustainable development: economics and policy. Oxford: Blackwell; 2000.

13. Myrdal, G. Asian drama. New York: Pantheon; 1968.

14. Todaro, M.P. Economic development. New York: Addison-Wesley; 2000. pp.

15. Harbison, F.H. Human resources as the wealth of nations. New York: oxford University Press; 1973.

16. Gallup, J.L. and Sachs, J.D. The economic burden of malaria. American Journal of Tropical Medicine and Hygiene. 2001; 64: 85-96.

17. Becker, G.S. Human capitals: A theoretical and empirical analysis with special reference to education. Chicago: The University of Chicago press; 1993.

18. Jones, A.M. and Kirigia, J.M. Health knowledge and smoking among South African Women. Health Economics. 1999; 8:165-169.

19. Kirigia, J.M. and Kainyu, L.H. Predictors of toilet ownership in South Africa. East African Medical Journal. 2000; 77: 40-45.

20. Jones, A.M. and Kirigia, J.M. The determinants of the use of alternative methods of contraception among South African women. Applied Economics Letters. 2000: 7:501-504.

21. Michael, R.L. The effect of education on efficiency in consumption. New York: National Bureau of Economic Research; 1972.

22. Kirigia, J.M. and Muthuri, L.H.K. Predictors of women's decision to ask new partners to use condoms to avoid HIV/AIDS in South Africa. East African medical Journal. 1999; 76: 484-489.

23. The World Bank. Better health in Africa: Experience and lessons learned. Washington, D.C.: The World Bank; 1995. 
24. Ram, R. The role of real income level and income distribution in fulfillment of basic needs. World Development. 1985; 13: 589-594.

25. Ross, L.W. and Shackleton, J.R. Economics for professional students. London: Castlevale; 1984. pp.

26. Fourie, F.C.N. How to think and reason in macroeconomics. Cape Town: Juta \& Co; 1999.
27. The World Bank Entering the $21^{\text {st }}$ Century: World Development Report 1999/2000. Washington, D.C.: The World Bank; 2000.

28. Stata Corporation. STATA 7.0. Texas: Stata press; 1984-2001.

29. Kirigia J.M., Sambo, L.G. and Kainyu L.H. Willingness-to-pay for schistosomiasis-related health outcomes in Kenya. African Journal of Health Sciences. 2000; 7: 55-67. 